\title{
TEACHING ENGLISH AS A FOREIGN LANGUAGE IN A BRAZILIAN PUBLIC SCHOOL IN BALSAS (MA) THROUGH COLLABORATIVE ACTIVITIES
}

\section{ENSINO DE INGLÊS EM UMA ESCOLA PÚBLICA DA BALSAS (MA) POR MEIO DE ATIVIDADES COLABORATIVAS}

\author{
Laíra de Cássia Barros Ferreira Maldaner ${ }^{1}$ \\ Mariana Noleto Barbosa ${ }^{2}$ \\ Selma Maria Abdalla Dias Barbosa ${ }^{3}$
}

\begin{abstract}
This research aimed to investigate the effects of using collaborative activities in English classes with 14 students with basic proficiency level of the $9^{\text {th }}$ grade of a Brazilian public school in Balsas (MA). Working with collaborative activities allows us to debunk the belief that English teaching in the Brazilian public schools does not work. Based on the sociocultural perspective, this research highlights the relevance of learning through interactions which learners use to build knowledge and argue about the language they are learning. The data analysis revealed that the collaborative tasks were fruitful to English teaching and learning as they promote socialization environments and develop self-esteem as well as the language proficiency.
\end{abstract}

Keywords: Sociocultural perspective; Collaborative learning; English Teaching

Resumo: O propósito deste estudo foi investigar os efeitos do uso de atividades colaborativas nas aulas de língua inglesa, com 14 alunos com nível básico de proficiência do $9^{\circ}$ ano do Ensino Fundamental de uma escola pública municipal da cidade de Balsas (MA). O trabalho com atividades colaborativas possibilita desfazer o mito de que o ensino de inglês na escola pública não funciona. Nessa perspectiva, esta investigação baseia-se na abordagem sociocultural, que salienta a relevância na aprendizagem por meio de interações através das quais os aprendizes constroem conhecimentos e argumentam sobre a língua que estão aprendendo. A análise dos dados revelou que as tarefas colaborativas foram profícuas para o ensino e aprendizagem de inglês, pois promovem ambientes de socialização e desenvolvem a autoestima, assim como o nível de proficiência na língua.

Palavras-chave: Perspectiva sociocultural; Aprendizagem colaborativa; Ensino de Inglês

\footnotetext{
1 Professora do Centro de Estudos Superiores de Balsas, da Universidade Estadual do Maranhão (UEMA). Doutoranda em Letras pela Universidade Federal do Tocantins (UFT). E-mail: laira_de_cassia@yahoo.com.br

${ }^{2}$ Mestranda do Programa de Pós-graduação em Letras: Ensino de Língua e Literatura (PPGL) pela Universidade Federal do Tocantins (UFT). Bolsista CAPES. Professora do Centro de Idiomas da UFT - Campus Araguaína e da Educação Básica. E-mail: noleto.nana@gmail.com

3 Professora Adjunta da Universidade Federal do Tocantins - UFT, campus de Araguaína. Doutora em Estudos Linguísticos pela Universidade Estadual Paulista Júlio Mesquita Filho-Unesp. Professora do Programa de PósGraduação em Ensino de Língua e Literatura (PPGL-UFT) e ProfLetras (Mestrado Profissional). E-mail: selmaabdalla@uft.edu.br.
} 


\section{Introduction}

It is on the news, on the internet, in music, fast food restaurants and even in mobile phone applications - although the English language may seem ubiquitous it is hardly used in Brazilian foreign language classrooms in public schools. Moreover, there is a core belief among students and teachers that it is impossible to achieve meaningful English language learning in the aforementioned context. In order to question this belief and stimulate language active practice and interaction, we have proposed a series of collaborative tasks in a Brazilian public school in Balsas (MA), hence this research aims to investigate how students responded to these activities.

The concept of collaborative learning is deeply rooted in Vygotsky's (1978) social constructivist theory of the mind where his concept of ZPD (Zone of Proximal Development) demonstrates that learning is attainable from the social context in which the learner is inserted as well as the interaction with a more experienced peer. Therefore, this notion indicates the importance of social interaction for the individual's development. We emphasize that a collaborative approach to English language teaching aims to create a meaningful teaching foundation in which two or more people stablish a learning relationship. Dillenbourg (1999) considers the development of collaborative activities among learners of a given language to be relevant, since they are able to acquire a greater knowledge from the interactions. Learners not only improve their listening, speaking, reading and writing skills, but also exchange experiences and develop problem-solving skills.

Our activities focused on a teaching process that took sociocultural aspects and the students' relationship with English learning into consideration, we believe that learning a language means much more than studying grammatical structures, the students need to acquire abilities that allow them to express their perceptions and beliefs in a meaningful way. Almeida Filho (2013) declares that abilities are essential for the learner's good development when led in a manner that provide communication among peers. According to this author, we should teach the English language competences and skills according to each student's needs, prioritizing the language's social practice.

In this article, we initially present the theoretical principles of the sociocultural perspective and the theories of collaborative English teaching. The following section presents 
the corpus analyses and the research methodology in the field school, where the teacherresearcher applied collaborative tasks and interviewed students followed by our final considerations.

\section{The sociocultural perspective}

The sociocultural perspective gives relevance to the mediation between the individual and a more experienced peer. According to Vygotsky (1978), since their birth, children are already inserted in a social world and the learning process happens through the interaction with other people. That means that the individual's ability to interact with the world around him is acquired from his birth. To the socio interactionist theory of the mind, the role of social and cultural institutions in the individual's cognitive development is paramount. It is through social interaction that the individual appropriates the cultural artifacts needed to mediate his actions and the cognitive processes (such as the memory and thought organization) in order to solve the problems found in the learning process.

According to Vygotsky (1978), the learner inserts himself in the construction of knowledge through the Zone of Proximal Development (ZPD), defined as distance between the learner's individual problem-solving level and what he or she can solve with guidance from and adult or in collaboration with more experienced peers.

It was possible to observe then that learning comes from social interaction and that the collaborative activities applied to English language teaching support knowledge mediation favoring the use and improvement of the language by its learners. Thus, language learning will be meaningful as it will lead students to solve problems with their peers and/or with and adult's guidance, motivating them and contributing to their peers' learning. As Swain (2001) exposes, it is through interaction that students are able to test their hypothesis and organize questions about the language they are learning. Well (1999) emphasizes that students who are skilled in one type activity can help their classmates and they may also need some assistance in another task and vice versa.

As mentioned earlier in this article, the sociocultural perspective aids the student as much as the English teacher as long as it allows the firsts to face and overcome obstacles in the learning process and, it guides the latter on how to conduct the teaching process at its best. It is worth reminding that each student has his or her own learning style, therefore the contribution 
of the socio-interactionist approach in the language learning development is indispensable.

Therefore, considering the ZPD a zone near development, according to Paiva (2014), the teacher will have the role of monitoring the students' learning levels, and then, proposing activities that will encourage collaborative learning in which students exchange experiences during task completion.

Still regarding the ZPD, the scaffolding metaphor calls the attention due to the mediation in the social interaction existent in the collaborative activity between learners especially concerning the most experienced learner, considering that this one, according to Donato (1994), helps the learner to develop his or her abilities, therefore, managing to improve his or her knowledge level.

\section{The collaborative approach in English language teaching}

The collaborative learning, as defined by Figueiredo (2006, p.12) "refers roughly to educational situations in which two or more people learn or try to learn something together." From this author's conceptions we can also highlight that the collaborative learning demand from students' team work in order to promote experiences and knowledge exchange. This mutual assistance, alongside with the interaction will lead to effective language learning.

It is noteworthy that collaborative learning allows students some sort of organization, in other words, it unites heterogeneous pairs aiming to achieve a common goal: using the English language in classroom interactions. Thus, according to the pillars of the sociocultural perspective, the process of building new knowledge should come from the students' previous knowledge and, it is the teacher's responsibility to encourage and instigate students with collaborative tasks that explore their learning potential and consequently, language practice.

There are several researches in the collaborative teaching field, we emphasize authors such as Figueiredo (2006), Tikunoff (1983), Dillenbourg (1999), and these studies have shown that teaching cannot be reduced to something static. On the contrary, it should be about pleasant strategies that encourage active and participative learning, in which the student is able to interact using the English language in different social situations. As Tikunoff (1983) states, students can develop interactional abilities through group activities. Here, this author, presents not only the relevance of collaborative activities do the learners, but also emphasizes the importance of classroom interaction. 
In collaborative teaching, unlike the traditional classes, where often words and sentences are copied on a blackboard followed by the command "translate it", the learners are invited to engage in active learning. In this approach, teachers and students act in a whole different mindset: classes are not static, knowledge is co-constructed instead of copied, activities are worked in a way that does not require translation, sharing strategies, beliefs, values and emotions; they become autonomous, hence, more critical and reflexive.

It is worth underlining that in order to make collaborative learning happen, the teacher must change his or her attitude towards English teaching and learning. This teacher has to understand that classes can be dynamic and collaborative, arising from each students' daily lives, allowing shared knowledge building opportunities that will also undermine the belief that "if they do not know Portuguese, how will they learn English?" This frame of mind shows not only self-indulgence but also demotivation and difficulty to open oneself to change, to what is new and different. There are no obstacles when creativity, incentive and willingness to teach are present. As we can observe, in order to think about desirable and meaningful teaching, truly concerned with the collective well-being of the classroom, the utopia, and the generous idea are needed, as we can see in the corpus analysis of the research.

\section{Corpus analysis}

In our ethnographic and qualitative research, we seek to apply dynamic and collaborative activities, originated from the sociocultural perspective contributions and based on Vygotsky's studies, to the English language classroom. This study was conducted on a $9^{\text {th }}$ grade group in junior high school in a public school in the city of Balsas (MA) with 14 participants. In short, we aimed to investigate how learners responded on different interaction situations in activities that they should complete in pairs.

Considering Vygotsky's concept of ZPD (Zone of Proximal Development), the school plays an important role in the development and improvement of the learner's communicative competence and skills. That given, it is the teacher's responsibility to promote such interactions in order to use the target language in a way that they can overcome the difficulties found in the English language teaching. Almeida Filho (2013, p. 82) asserts the relevance of the communicative teacher as he or she "raises the group's expectations, code their topics and subjects, prepares the moment and the forms of contact with the new language and, above all, 
create or maintains a fair learning rhythm for the students."

As the aforementioned author affirms, the role of the teacher in the students' learning motivation brings benefits to a teaching based on language use and practice in an interactive way, preparing the student to perform different social functions of language, as we will demonstrate with the reports of seven activities as followed.

\subsection{Collaborative activities in the English language classroom}

This research took place in a junior high school in the city of Balsas (MA) and focused on a $9^{\text {th }}$ grade group. In Brazil, English as a foreign language is a mandatory subject from the $6^{\text {th }}$ grade on, notwithstanding all the 14 students who participated in this research are considered beginners.

One of the instruments used in this research is the field diary, which is widely used in ethnographic research. In this diary the teacher researcher registered her impressions on how students engaged and reacted to the proposed tasks. Even though the field diary might be a quick and easy research instrument, as Falkembach (1987) asserts, it must be combined with other investigation techniques, that is why we have also applied a questionnaire, in order to understand the learner's perceptions about the collaborative process.

The activities proposed by the teacher researcher aimed to develop and improve the four skills of the language: listening, reading, writing and speaking by the means of interaction. In this section we present the tasks proposed to the participants.

\section{Activity 1: Organizing a dialog}

The students are organized in pairs and then, they received a handout containing a scrambled dialog. They were supposed to put the conversation in order and later write it down on another sheet. This type of activity can provide a number of situational short dialog in which a specific linguistic function can be targeted and each situation can be practiced multiple times. According to the field diary entry, it was possible to observe interaction within each pair. Even though the learners struggled with communicative skills, they were able to complete the task successfully. Almeida Filho (2013) states that it is only because of group's ability to build a trust environment that the students are able to work together, overcoming their difficulties. 
Activity 2: Storytelling using pictures

This activity was composed of fifteen pictures that told the story of a twelve-year-old girl who enjoyed reading in the farm where she lived. Her dreams were interrupted when her father decided to sell her to a town merchant. The girl was forced to work in a sweatshop but after a few months of suffering, a kind lady decides to help her, taking her to study in a school in town. For the completion of this task, the learners were told that they should organize events in the pictures in chronological order, and later, the pairs were supposed to tell the story orally followed by collaborative writing. This type of task has many benefits to the EFL learner: besides being fun and motivational it allows them to not only improve their speaking skills, but also to develop creativity and imagination as well as skills such as predicting, hypothesizing, guessing and message decoding.

During the completion of this activity it was possible to notice that the students felt more confident to take risks with their oral language as their partner was there to help them in the construction of the narrative.

\section{Activity 3: Song activity}

Literature on the benefits of using music in English classes is extense. Gatbonton and Segalowitz (1988) songs can develop automaticity, defined by them as "a component of language fluency which involves both knowing what to say and producing language rapidly without pauses." Domoney and Harris (1993) and Little (1983) found that music is a major source of English outside the classroom, exposing students to real language in use, colloquial and idiomatic expressions. Finally, it is possible to say that using music is one of the easiest ways of motivating EFL learners.

Despite the numerous benefits of music in the EFL classroom, the students participating in this study have rarely been exposed to it. That is why we have decided on a gap-filling task using Avril Lavine's Tomorrow. The choice for an acoustic version of the song was made in order to allow them more time to write down the missing words. Even though they were not familiarized with tasks such as this, we observed excellent interaction between partners and great sense of achievement. 
Puzzles are widely used in ESL classes, specially to teach vocabulary. A study conducted with Palestinian $10^{\text {th }}$ grade students showed that puzzles helped students retain more of the taught vocabulary, achieving better outcomes in tests (Keshta and Al-Faleet, 2013) In this game-like activity we aimed to help students learn irregular verbs, a topic which usually causes distress, in a fun way. Each pair would receive a word search puzzle containing 15 irregular verbs and a card with the base form of these verbs. The pair who finds all the verbs would win. The field diary entry reported that the students were really focused and engaged in this activity.

\section{Activity 5: Illustrated Spelling Bee}

In the illustrated spelling bee, each pair received sheets of paper, some of these sheets contained pictures, and the students were instructed to write what they saw on these pictures on the others. Right after the teacher-researcher gave the instructions, the students wrote the words that correspondent to the pictures, thus, practicing their writing skills. Encouraging and promoting students' participation through collaborative activities is essential, considering that it improves their performance and self-esteem significantly. As stated by Vygotsky (1978), the interacting with other people and cultural artifacts change the way children act and behave. Therefore, collaborative activities involve the learners in the understanding and interaction inside specific learning situations.

\section{Activity 6: Open cloze}

In an open cloze exercise, students receive short texts with some gaps that should be filled. In this activity, the participants received a text about the importance of reading and they had to work together to make decisions about what words were more appropriate to complete each gap. Not only did the learners needed to interact, they also had to make use of a series of reading strategies in order to solve the problems presented by the task, as Nyikos and Hashimoto (1997) declare, learning is determined by more than one learner. Thus, opinions, beliefs among learners at the time of interaction unite in a collaborative dialogue elucidating what might have seemed difficult to solve. 
This activity consisted of two parts. In the first moment, the learners received a series of questions, however, the words were shuffled and they were asked to put them in order. All the questions were about the relevance of studying English and, that leads us to the second moment, when they were invited to answer those questions hence, using their oral skills in order to reflect about their own learning process. They were shy at first, nonetheless, the presence and support of their partners encouraged and helped them overcome this difficulty.

Throughout the research, the pairs of students participated in collaborative tasks developed according to the pillars of sociocultural theory. As the activities were presented, they had to discuss about the texts and propositions with one another, giving suggestions and expressing their critical point of view. The benefits of working in pairs are noteworthy. As stated by Vygotsky (1978), it is through the interaction with adults or more experienced peers that children can develop psychologically.

\subsection{Analysis of the interviews}

After the teacher-researcher concluded all the tasks with the learners, they were invited to answer an interview composed of five closed questions. In some cases, the students were asked follow-up questions. With these, we intended to assess the students understanding and perceptions about the collaborative teaching-learning process. This section of the article presents the questions asked to the students and the results found.

Question 1: Is it important to work in pairs during the collaborative activities? Yes or No?

When asked about the importance of working in pairs during the activities in the English classes, 11 out of 14 students answered yes. (78,5\%). Only 3 students did not consider the pair work important to their language learning. Even though these three students expressed disagreement to the collaborative approach, they mentioned that motivation to develop the four skills of the language is essential in the English class.

Question 2: What was your opinion about the collaborative activities used in class? Great, good or bad? 
10 out of $14(71,5 \%)$ students stated that the collaborative activities used in class were "great", whilst 3 of them $(21,5 \%)$ evaluated that the activities as "good" because they promoted interaction with their partners. However, $1(7 \%)$ student considered the collaborative activities "bad". This student expressed preference for individual activities because when working in pairs, there were always the need to come to an agreement and compromise. Therefore, we believe that this answer is more related to a student's personal preference than to a problem in the activities development.

Question 3: Is it possible to learn through interaction? Yes or no?

11 students $(78,5)$ students stated that it is possible to learn through interaction, while 3 $(21,5)$ consider that it is not possible. They declared that there are always students who want to attract more attention. This result demonstrates the importance of communication as it leads to experience exchanging and consequently to pleasant learning, without impositions.

Question 4: Do you think it is relevant that the teacher proposes collaborative activities? Yes or no?

$100 \%$ of the students agreed that the use of various types of collaborative activities is paramount to better learning. The need of different, dynamic, collaborative tasks is evident in the graph as these improve the use of the target language by the students.

Question 5: Would you like to work with collaborative tasks again? Yes or no?

$13(93 \%)$ out of 14 students declared that they believe that collaborative activities should be part of the lesson plan, emphasizing that they improve communication between classmates. However, one student (7\%) declared that he or she prefers to work alone and that working in pairs can be complicated. Once again, we understand that this answer is related to the student's personal preference.

This study, involving students of the $9^{\text {th }}$ grade of junior high school, conducted according to the principles of collaborative teaching allowed us to observe that the public school students need only of incentive, motivation and more dynamic classes in order to develop their potential. We also conclude that the collaborative activities applied in the course of this research 
favored meaningful learning and communication in the target language as a result of the careful way they were conceived, considering the students' sociocultural reality.

It is also important to mention the studies conducted by Paiva (2010), in which she emphasizes that each student has a particular learning style and it is the teacher's responsibility to develop dynamic activities that stimulate interaction, the use of the English language contemplating these different learning styles.

\section{Final considerations}

With this research, it was possible to demonstrate that the use of collaborative activities in the public schools only benefit the English classes. We found that these activities improve the students' self-esteem, favored the exchange of experiences as well as developing their linguistic competence. The school, on the other hand, plays an essential role in the students' collaborative learning, as it is through the ZPD that the teacher can connect the students' practice to the solution of problems they have found during the interaction in the activities.

Considering this research findings, it is necessary to lead the English teaching under the principles of sociocultural theory and collaborative learning in order to build learning that is more meaningful. Hence, we reiterate our conclusions regarding the contributions of collaborative activities to the teaching-learning process of the English language.

Given the above, we believe that if teachers and schools do their share, the students will surely benefit from the collaborative work, climbing up the steps of knowledge, leaving the idea that English classes are all about translation behind and making meaningful use of it. While mentioning the benefits of collaborative teaching, it is important to mention Pinho e Lima's (2015) understanding that collaborative teaching promotes interaction in the EFL classroom as well as learning development. We perceived that interaction and collaboration motivated students, helped them improve their linguistic skills, and their self-esteem.

\section{References}


ALMEIDA FILHO, J.C. P. Dimensões comunicativas no ensino de línguas. Campinas: Pontes: 2013.

DILLENBOURG, P. What do you mean by collaborative learning. In: DILLENBOURG, P. (Ed.). Collaborative learning: cognitive and computational approaches. Oxford: Elsevier, 1999. P. 1-19.

DOMONEY, L. \& HARRIS, S. Justified and ancient: Pop music in EFL classrooms. ELT Journal, 47, 234-241., 1993.

DONATO, N. Collective Scaffolding in Second Language Learning Teaching. In: LANTOLF, J. P.; APPEL, G. (ORGS.). Vygotskian Approaches to Second Language Research. Norwood: Ablex, 1994. P. 35-36.

FALKEMBACH, E. M. F. Diário de campo: um instrumento de reflexão. In: Contexto e educação. Ijuí, RS Vol. 2, n. 7 (jul./set. 1987), p. 19-24

FIGUIREDO, Francisco José Quaresma. A aprendizagem colaborativa. Goiânia: Ed. da UFG, 2006.

GATBONTON, E. \& SEGALOWITZ, N. Creative automatization: Principles for promoting fluency within a communicative framework. TESOL Quarterly, 22, 473-492., 1988.

KESHTA, A. S. \& AL-FALEET, F. K. The effectiveness of using puzzles in developing Palestinian tenth graders' vocabulary achievement and retention. Humanities and Social Sciences. Vol. 1, No. 1, 2013, pp. 46-57. doi: 10.11648/j.hss.20130101.16

LITTLE, J. Pop and rock music in the ESL classroom. TESL Talk, 14, 40-44., 1993.

PAIVA, V. L. M. O. Aquisição de segunda língua. 1. ed. São Paulo: Parábola Editorial, 2014.

PAIVA, V. L. M. O. Práticas de ensino e aprendizagem de inglês como foco na autonomia. Campinas, SP: $3^{\text {a }}$ edição. Pontes Editores, 2010.

SWAIN, M. Integrating Language and Content Teaching Through Collaborative Tasks. The Canadian Modern Language Review, v.58, n. 1, p.44-63, 2001.

TIKUNOFF,W.J. Utility of SBIF features for the instruction of limited English proficient students. Report No. SBIF-83-R.15/16 for NIE Contract No. 400-80-0026.San Francisco: Far West Laboratory for Educational Research and Development, 1983.

VYGOTSKY, L. S. (1978). Mind in society: The development of higher psychological processes. Cambridge, Mass.: Harvard University Press.

WELL, G. The zone of proximal development and its implications for learning and teaching. 
In: Well G. (ED.). Dialogic inquiry: towards a sociocultural practice and theory of education. New York: Cambridge University Press, 1999.

Recebido em 27 de dezembro de 2018. Aceito para publicação em 21 de maio de 2019. 